\title{
Hvorfor smiler vi?
}

\author{
En mann uten smil skal ikke åpne butikk, sier et kinesisk ordtak. Da burde kanskje flere \\ kvinner enn menn åpne butikk, skal vi tro en uhøytidelig undersøkelse fra 1980.
}

$\AA$ smile er egentlig noe ganske mystisk. Det forekommer i utrolig mange sammenhenger, og slike bevegelser av munnvikene involverer en rekke forskjellige muskler. Det er også pussig at øynene våre avslører om vi virkelig smiler eller om vi bare later som. Egentlig deltar hele ansiktet i smileprosessen, og av og til har også kroppen medbevegelser. Smiling forekommer også i dyreverdenen, og vi vet at hester kan både smile og le. Ingen ting er så kostelig som en lattermild hest, selv om det er et sjeldent syn.

Egentlig er smil en måte å kommunisere emosjoner på, men på verdensbasis kan det være store kulturelle forskjeller. I noen land blir smiling oppfattet som en negativ ytring, og det hevdes at japanere smiler først og fremst når de er forvirret eller sinte. Noen biologer går så langt som til å hevde at smilet oppsto under evolusjonen for om lag 30 millioner år siden og var en måte å uttrykke angst på. Derved signaliserte urmenneskene til fiendene sine at de var ufarlige og underkastet seg. Men i dag kan smil være en måte å vise overlegenhet på. Smil kan virke seksuelt tiltrekkende og det kan også være en måte å kommunisere på. Et spontant smil hos nyfødte er en måte å få kontakt på og samtidig et sterkt signal om at babyen er i ferd med å dukke opp fra «urmørket» og bli blant oss.

Veterinær og mangeårig professor i fysiologi, Weiert Velle (1925-2007) var en internasjonalt kjent forsker på kjønnshormoner. Han var også en debattglad mann og ikke redd for å si sin mening. Etter at han utga flere artikler og en bok i 1980årene der han skrev om kjønnshormoner og atferd, ble det sterk reaksjon. Da Velle hevdet at biologiske forskjeller mel- lom mann og kvinne ikke forsvinner ved kjønnsnøytral barneoppdragelse, kastet han på den tiden ut en brannfakkel (1). Denne konklusjonen provoserte kretser innen kvinnesak og likestilling som mente at all kjønnsbetinget atferd var tillært.

Men Velle var ikke redd for å svare på angrepene. I tillegg tillot han seg en aldri så liten vitenskapelig spøk. Fra den årlige høytideligheten under immatrikulering av studenter ved henholdvis Landbrukshøgskolen og Idrettshøgskolen hadde han observert at jentene smilte mye mer enn guttene. Dette måtte undersøkes nærmere, så fra tilskuerplass begynte han å krysse av hvem som smilte til rektor eller direktør. Her fremkom det store kjønnsforskjeller, og disse funnene publiserte han i Norsk Veterinærtidsskrift i 1980. Artikkelen er et historisk eksempel på såkalt «motstrømsforskning» som vi fortsatt kan tillate oss å smile av - uten at dette smilet behøver å være et uttrykk for angst!

\section{Ole Didrik Lærum}

ole.laerum@gades.uib.no

Ole Didrik Lærum (f. 1940) er professor (adj.) ved Københavns Universitet og professor emeritus ved Gades institutt, Universitetet i Bergen.

\section{Litteratur}

1. Landsverk T, Sjaastad Ø. Minnetale over dr.med.vet. Weiert Martin Velle. Årbok. Oslo: Det Norske Videnskaps-Akademi, 2007: 146-60. www.dnva.no/c41070/ artikkel/vis.html?tid=41092 (23.9.2012)

\section{Seriøse smilestudier}

Weiert Velle. Seriøse smilestudier. Norsk Veterinærtidsskrift 1980; 92: 12

Tungtveiende kjønnsforskjeller ( $p=$ langt mindre enn 0,001) $i$ smiledisposisjonsprevalens registrert hos selekterte 21( \pm )-åringer $(n=121+211) i$ Norge høsten 1980.

\section{Innledning}

I sosiobiologisk sammenheng knytter det seg stor interesse til de signaler og signalsystemer som benyttes i kommunikasjonen mellom individer innen de forskjellige arter. Hos primater, dvs. menneske og aper, og sjeldnere hos katt og hest, er smilet et likt signal, men bruken av smilet som signal har likevel vært gjenstand for en relativt beskjeden forskningsinnsats. Når det gjelder menneske, foreligger det data som viser at den såkalte reflekssmiling (ubevisst) er hyppigere hos nyfødte piker enn hos gutter, og at piker i den første del av oppveksten viser et mer stabilt smilemønster enn gutter. Disse observasjoner hviler på et trygt metodologisk grunnlag.
Det er også foretatt enkelte systematiske undersøkelser over smilefrekvens hos voksne personer. I den ene undersøkelsen besto materialet av gruppebilder av collegestudenter fra årene under og etter første verdenskrig. Til tross for at det totale antall personer som smilte var relativt lavere under enn etter krigen, viste materialet som helhet at prosentvis langt flere 
piker enn gutter smilte på disse bildene. Ved denne undersøkelsen heftet det imidlertid antakelig en metodologisk feil, idet fotografene på den tiden nesten bare var menn, noe som må antas å ha innbudt til smil fra flere piker enn gutter. Denne feilkilde kan på den annen side tenkes i hvertfall i noen grad å ha blitt motvirket av det forhold at fotografene på den tiden som regel skjulte hodet under et svart klede under gruppefotograferinger. Hva materialet angår, besto forsøkspersonene av en relativt homogen gruppe, særlig hva alder angår.

I den andre undersøkelsen det skal refereres til tok observatørene oppstilling anonymt på undergrunnsstasjoner i New York og registrerte fortløpende antall forbipasserende kvinner og menn og hvor mange av hvert kjønn som smilte. I denne undersøkelsen er det ikke angitt noen bestemt nedre aldersgrense i materialet. Heller ikke var det mulig å fastslå spredningen i alder. Dessuten må de observerte personer antas å ha vært i vidt forskjellige situasjoner i observasjonsøyeblikket, på vei til eller fra gledelige eller sørgelige begivenheter e.l. Selve tidspunktet på dagen (eller natten) da observasjonene ble gjort kan også tenkes å ha influert på resultatet (mange mennesker er spesielt sure om morgenen). Disse usikkerhetsfaktorer er ikke adekvat drøftet i avhandlingen. Likevel fant man også i denne undersøkelsen betydelig høyere smilefrekvens hos kvinner enn hos menn, uten at årsaken til dette ble nærmere utredet.

Formålet med den undersøkelsen som her skal beskrives har vært å søke klarlagt den relative smilefrekvens hos de to kjønn av noenlunde ensartet alder under så standardiserte betingelser som mulig med hensyn til tidspunktet på dagen, situasjon i observasjonsøyeblikket hva angår såvel lys- og temperaturforhold (i kaldt vær blir man stiv i masken) som når det gjaldt psykisk belastning. Man har ikke her tatt sikte på å differensiere mellom de forskjellige typer av smil, kun om det ble smilt eller ikke.

Problemstillingen kan kanskje av noen betraktes som søkt. En har imidlertid ansett det vesentlig å få fastslått om slike kjønnsforskjeller som nevnt ovenfor virkelig eksisterer, idet målet må være å skaffe tilveie faktiske kunnskaper med sikte på å fjerne ulikheter. Dette vil være et ledd i den generelle utjevningspolitikk, og dette arbeidet kan derfor betraktes som et bidrag til aksjonsforskningen.

\section{Materiale og metoder Forsøk A.}

Materialet besto av 193 personer, de aller fleste i alderen 20-22 år, herav 58 kvinner og 135 menn. Hva kjønnsfordeling angår, hefter det en liten usikkerhet til materialet, idet en av observandene hadde en bekledning kombinert med så mye hår (og dessuten manglende skjegg) at det var umulig med sikkerhet å fastslå kjønnet.

Som observasjonssted ble valgt Auditorium maximum ved Norges landbrukshøgskole, idet denne salen er av bra størrelse, har relativt gunstige temperatur- og belysningsforhold, og dessuten et sceneteppe som gir god bakgrunn for observasjoner av denne type. Undersøkelsen fant sted 20. august 1980 fra ca. kl. 13 og utover, under immatrikuleringen av årets nye studenter og det var disse som utgjorde det observerte materiale.

Observandene stammet fra de forskjelligste deler av landet, og fra ulike sosiale miljø, og må således anses som relativt representative ihvertfall for landsdeler og dermed forbundet lynne.

Observasjonstidspunktet ble begrenset til den korte periode det tar for studenten fra hun eller han er ca. 5 meter fra rektor og til immatrikuleringsbeviset er overlevert og håndslaget med rektor er gitt. Observatøren kunne selvsagt ikke fritt velge rektor, idet han på forhånd var valgt av kollegiet. I dette tilfelle dreiet det seg om professor dr. agric. Ola Heide. En svakhet ved rektor Heide rent metodologisk sett var at han smilte til hver enkelt han ga håndslag, men såvidt observatøren kunne bedømme smilte han ikke mer eller bedre til de kvinnelige enn til de mannlige studentene. Helt sikker på dette kan man imidlertid ikke være.

Observatøren var slik plassert at det var fritt utsyn frem til dem som skulle observeres. Likevel bød observasjonene enkelte, men dog meget få ganger på problemer, idet observandene snudde ansiktet så sterkt mot rektor at det ble vanskelig for observatøren å registrere ansiktsuttrykket nøyaktig.

\section{Observasjonsmetoden besto i visuelt} å fastslå hvorvidt vedkommende smilte eller ikke smilte, etter det såkalte «alt eller intet»-prinsipp. Stort sett bød ikke dette på problemer, men en sjelden gang var det vanskelig med absolutt sikkerhet å avgjøre om det forelå et smil, eller om kun vedkom-

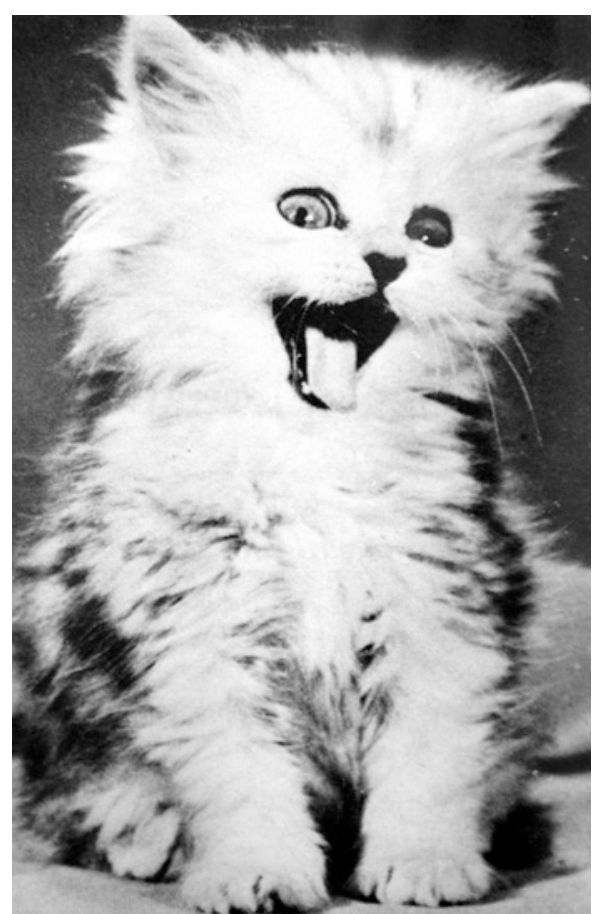

mendes ansiktsuttrykk på mer permanent basis var av den blide type som selv i nøytral stilling kan tolkes som smil. Antall slike tilfelle var imidlertid ikke stort, og influerer neppe på tolkningen av den generelle trend $\mathrm{i}$ resultatene.

\section{Forsøk B.}

Materialet besto her av 139 personer, med gjennomsnittsalder $231 / 2$ år, 63 kvinner og 76 menn. Som observasjonssted ble her valgt aulaen ved Norges idrettshøgskole, selv om belysningsforholdene kunne late noe tilbake å ønske. Temperaturforhold og bakgrunn var imidlertid også her gunstige. Denne del av undersøkelsen fant sted 22. august 1980 , også om dagen, men på et noe tidligere tidspunkt, fra ca. kl. $11 \mathrm{og}$ utover. Tidsforskjellen mellom forsøk A og forsøk B må imidlertid kunne anses uten betydning.

Også i denne del av undersøkelsen var det årets nye studenter som utgjorde forsøksmaterialet, med generelt sett det samme metodeopplegg som beskrevet under forsøk A. Håndslaget ble her gitt av direktør Thor Volla, som om mulig smilte enda mer uttalt til hver enkelt enn den rektor som er omtalt under forsøk A, men igjen uten at man med statistisk sikkerhet kan si at smilene gitt til de kvinnelige studenter var mer intense enn til de mannlige. 


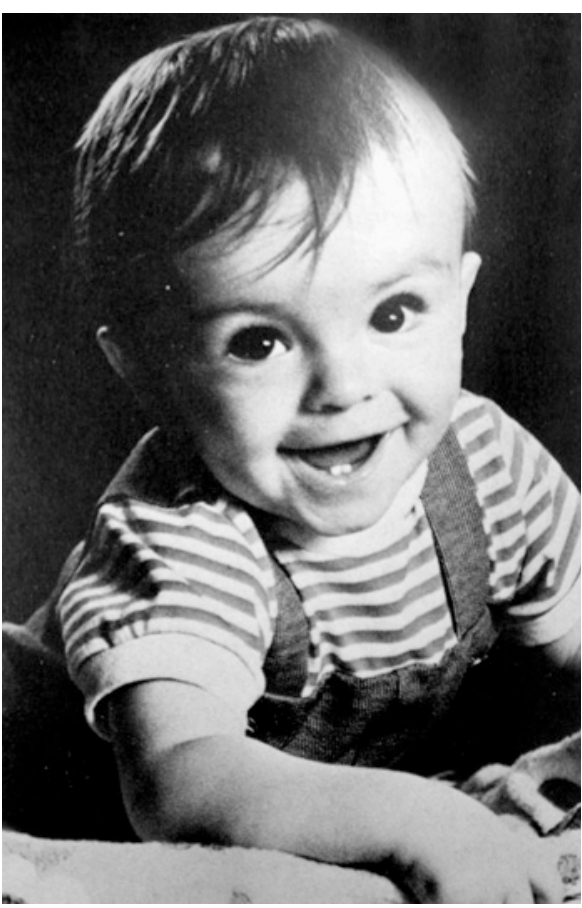

\section{Resultater}

Resultatene fremgår av tabell 1 og viser at i begge undersøkelser var det prosentvise antall som smilte mye høyere blant kvinner enn hos menn.

I såvel forsøk A som forsøk B var forskjellen i smilefrekvens mellom de to kjønn statistisk høyt signifikant, bedømt ved FisherIrwin-testen. I virkeligheten sprengte forskjellene tabellen.

\section{Diskusjon}

Det er flere forhold som det kan være grunn til å diskutere nærmere i denne forbindelse.

Hva materiale angår, kan man knapt si at det er representativt for befolkningen som helhet. Man kan derfor ikke, selv om antall personer som inngår i undersøkelsen ikke er ubetydelig, påstå at norske kvinner totalt sett smiler ca. 4 ganger så mye som menn.
Dessuten må en huske på at dette var en nokså spesiell situasjon som man vanligvis bare opplever en gang i livet.

Minst like betydningsfullt er imidlertid at man ut fra de opplysninger som foreligger ikke kan si noe om antall observander fra hver landsdel står i forhold til befolkningstettheten i vedkommende landsdel. Dette gjør tolkningen av resultatene enda mer usikker, idet jo den oppfatning har gammel hevd at sørlendinger smiler mer enn f.eks. vestlendinger, for ikke å snakke om østerdøler. Dersom dette er tilfelle, hvilket vi ikke har noen grunn til å betvile, vil selvsagt skjev representasjon fra de enkelte landsdeler kunne trekke resultatene opp eller ned, alt ettersom. En fordel ved materialet er imidlertid den relativt beskjedne spredning i alder. På den ene side utelukker dette at bitre erfaringer f.eks. fra tredveårene setter sitt preg på en del av materialet, samtidig som på den annen side livets bitre realiteter i vår egen tidsepoke knapt kan ha begynt å gjøre seg gjeldende hos observandene. Men selvsagt medvirker også dette til å begrense utsagnskraften når det gjelder de resultater som er oppnådd.

Minst like viktig som å diskutere materialet er det imidlertid å gå litt nærmere inn på det metodologiske opplegg som bare delvis ble analysert under avsnittet Materiale og metoder. I sentrum står her spørsmålet om den person som studentene gir håndslaget til kan tenkes (ufrivillig) å innvirke på resultatet. Det må her innskytes at intet på forhånd var avtalt mellom observatør og rektor, hhv. direktør om at undersøkelsene i det hele tatt skulle foretas. Det samme gjaldt selvsagt vis-à-vis studentene. Likevel må en regne det som endog sannsynlig at en mannlig rektor/direktør vil stimulere til flere, respektive penere smil fra den kvinnelige del av populasjonen enn fra den mannlige, i disse tilfelle så meget desto mer som de to angjeldende personer i mange kretser anses for å være litt av noen sjarmører. På den annen side tør det by på store problemer noen gang å fremskaffe en fullstendig

Tabell 1 Smilefrekvens vist av kvinnelige og mannlige studenter overfor rektor/direktør i en immatrikuleringssituasjon.

\begin{tabular}{|c|c|c|c|c|c|}
\hline Forsøk & Kjønn & $\begin{array}{c}\text { Antall } \\
\text { observander }\end{array}$ & $\begin{array}{l}\text { Antall som } \\
\text { smilte }\end{array}$ & $\begin{array}{l}\text { Prosent som } \\
\text { smilte }\end{array}$ & $\begin{array}{c}p \text {-verdi } \\
\text { på kjønnsforskjell }\end{array}$ \\
\hline \multirow[t]{2}{*}{ A } & Kvinner & 58 & 31 & 53,45 & \\
\hline & Menn & 135 & 15 & 11,11 & $p \ll 0,001$ \\
\hline \multirow[t]{2}{*}{ B } & Kvinner & 63 & 49 & 77,77 & \\
\hline & Menn & 76 & 16 & 21,05 & $p \ll 0,001$ \\
\hline \multirow[t]{2}{*}{ Totalt } & Kvinner & 121 & 80 & 66,11 & \\
\hline & Menn & 211 & 31 & 14,69 & $p \ll 0,001$ \\
\hline
\end{tabular}

kjønnsløs rektor/direktør. Forutsetningen for at undersøkelser av denne spesielle art i det hele tatt skal kunne gjennomføres, er derfor at programmet legges opp som to delundersøkelser, den ene del med mannlig rektor/direktør, den annen med kvinnelig. Den foreliggende avhandling må derfor kun oppfattes som første trinn i et totrinnsprogram, idet en tar sikte på å gjennomføre neste trinn når Norges landbrukshøgskole og Norges idrettshøgskole har fått kvinnelig rektor, henholdsvis direktør, idet settingen forøvrig jo bør være så lik som mulig med den som forelå i forsøkene A og B beskrevet $\mathrm{i}$ denne avhandling. Men selv om dette lar seg realisere, vil likevel et nytt forsøk på landbrukshøgskolen antakelig komme til å måtte bygge på noe endrede forutsetninger. Innen en kvinnelig rektor blir valgt på Norges landbrukshøgskole vil utvilsomt studentersamfunnets nybygg stå ferdig. Dette vil kunne medføre at den totale smilefrekvens blant landbruksstudenter da vil bli betydelig høyere enn nå. På den annen side vil antakelig frekvensøkningen gjøre seg gjeldende i like stor grad hos begge kjønn, slik at noe verdifullt likevel vil kunne komme ut av undersøkelsen. For begge institusjoner vil imidlertid oppstå problemet med å skaffe kvinnelig rektor/direktør med like inntagende smil overfor menn som de nåværende etter det som er opplyst har overfor kvinner.

Hva den av observatøren benyttede metode for registreringer angår, bør det også nevnes at det i enkelte tilfelle var nærmest umulig å observere ansiktsuttrykket hos materialet akkurat idet håndslaget fant sted. Det er derfor mulig at frekvensen er noe lavt anslått, men dette vil gjelde begge kjønn. Forøvrig var det påfallende at de kvinner som smilte, gjennomgående påbegynte smilet $\mathrm{i}$ lengre avstand fra rektor/ direktør enn de menn som smilte. Hos disse siste ble smilet ofte registrert som nærmest et raskt glimt over ansiktet, mens det hos hovedparten av kvinner altså varte lenger og virket mer inderlig. Under observasjonenes gang og ved den senere presentasjon av resultatene har en imidlertid valgt å ikke gradere intensiteten, idet det kunne ha medført feil i de løpende noteringer. Slike omfattende registreringer måtte i tilfelle bli gjenstand for nye undersøkelser.

Spørsmålet om årsaken til den utpregede forskjell som er registrert i dette og tidligere arbeider er foreløpig uklart. Sannsynligvis dreier det seg her om en funksjon som er nøye programmert med kjønnsforskjeller i selve det genetiske apparat. Men man kan selvsagt ikke utelukke at miljøskader kan influere, f.eks. slik at gutter smiler mindre enn piker. Spørsmålet om det er arven eller miljøet som er hoveddeterminant melder seg derfor også på dette område med full styrke. Det synes dog å være lite sannsynlig at den 
tidlige reflekssmiling som er hyppigere hos piker enn hos gutter like etter fødselen skulle være resultat av oppvekstmiljøet, da denne form for smiling foregår før utenverdenen har fått satt noe særlig preg på individene, og den dessuten foregår i de perioder da barna sover. Intet er imidlertid fullt bevist i denne sak, så det ligger her rike muligheter for fremtidig forskning. Hva angår den sosiobiologiske betydning av de funn som her er gjort og som forsåvidt bekrefter tidligere undersøkelser fra USA, er det meningen å ta diskusjonen om dette meget ømtålelige tema opp som avslutning av forskningstrinn nr. 2, når det måtte bli mulig å realisere dette. Inntil da må de resultater som her er fremlagt få tale for seg selv.

\section{Sammendrag}

I to observasjonsserier ble smilefrekvensen hos kvinnelige og mannlige studenter registrert under tilnærmet standardiserte betingelser i en immatrikuleringssituasjon der håndslaget ble gitt til en mannlig rektor/ direktør.

I det samlede materiale som besto av 332 personer, 121 kvinner og 211 menn, var smilefrekvensen hos kvinner 66,11 prosent, hos menn 14,69 prosent. Denne forskjell er statistisk høyt signifikant ( $\mathrm{p}<0,001)$.

Mulige feilkilder samt opplegg for videre forskning på området diskuteres.

\section{Weiert Velle}

Professor

Norges veterinærhøgskole

Postboks 8146, Dep.

Oslo 1

\section{Litteratur}

Freedman, D.G.: Human Infancy: An Evolutionary

Perspective, Erlbaum, New Jersey, 1974.

Kagan, J.: Changes and Continuity in Infancy. Wiley, New York, 1971

Korner, A.F.: Neonatal startles, smiles, erections, and reflex sucks as related to state, sex, and individuality. Child Development 1969,40,1039-53.

Wilson, E.O.: On Human Nature. Harvard University Press, 1978. 